\title{
Farmer Preferred Traits and Potential for Adoption of Hybrid Rice in Ghana
}

\author{
Samuel Oppong Abebrese ${ }^{1}$, Edward Martey ${ }^{1}$, Paul Kofi Ayirebi Dartey ${ }^{2}$, Richard Akromah ${ }^{3}$, Vernon Edward \\ Gracen $^{4}$, Samuel Kwame Offei ${ }^{4} \&$ Eric Yirenkyi Danquah ${ }^{4}$ \\ ${ }^{1}$ CSIR-Savanna Agricultural Research Institute, P.O. Box TL 52, Tamale, Ghana \\ ${ }^{2}$ CSIR-Crops Research Institute, P. O. Box 3785, Fumesua, Kumasi, Ghana \\ ${ }^{3}$ Department of Crop and Soil Sciences, KNUST, Kumasi, Ghana \\ ${ }^{4}$ West Africa Centre for Crop Improvement, University of Ghana, Legon, Ghana \\ Correspondence: Samuel Oppong Abebrese, CSIR-Savanna Agricultural Research Institute, P.O. Box TL 52, \\ Tamale, Ghana. E-mail: sam555oppa@yahoo.com
}

\author{
Received: April 25, 2019 Accepted: May 16, 2019 Online Published: June 30, 2019 \\ doi:10.5539/sar.v8n3p38 URL: https://doi.org/10.5539/sar.v8n3p38
}

\begin{abstract}
Hybrid rice (Oryza sativa L) cultivars exploit hybrid vigor to break the yield ceiling of their inbred counterpart thereby increasing productivity per unit area. Crop varieties released in developing countries are often poorly adopted as a result of their failure to meet farmer and consumer trait preferences. This study was therefore conducted to identify key farmer preferred traits, assess farmers' general rice agronomic practices and the potential for adoption of hybrid rice through formal and informal survey approaches. Farmer preferred traits include high yield, early maturity, and good grain quality, but few others, their preferences varied according to location. High cost of hybrid rice seeds was identified as a major challenge. There will be the need for reasonable pricing such that the return from growing hybrid seed is high enough for farmers to recognize the value of growing hybrids. Forty per cent $(40 \%)$ of the responding farmers were found to employ seed wasting practices such as broadcasting and dibbling. Farmers gave mistrust and unreliable seed supply as the main reasons for their low patronage of the formal seed system. Only two per cent $(2 \%)$ of the responding farmers purchase seeds from private seed companies. It will be necessary to revamp the formal seed system to encourage farmer patronage and private sector involvement for successful roll out of hybrid rice technology in Ghana. Considering the expected yield advantage $(>50 \%)$ and the price farmers will like to pay $(\mathrm{GH} \phi 3.3 ; \$ 0.8)$, the prospects of hybrid rice adoption could said to be low.
\end{abstract}

Keywords: hybrid rice, varietal trait preferences, improved variety adoption, productivity improvement

\section{Introduction}

Rice (Oryza sativa L) is increasingly replacing the traditional Ghanaian staples like plantain, sorghum and millet as a result of its ease of cooking and changes in consumer preferences especially in the urban centers (Tanko \& Amikuzuno, 2015). Ghana depends on imports for about 50\% of her rice needs annually (Asante et al., 2013; Ragasa \& Chapoto, 2017). Efforts are being made to introduce to farmers technologies that enable increase of production and productivity to reduce imports. One technology for genetically improving the yield potential of rice is through the use of hybrid varieties (Cheng et al., 2007; Yuan, 2017). Hybrid rice varieties make it possible to surpass the yield plateau of the current semi dwarf inbred varieties (IRRI, 1997; Shi-hua, Li-yong, Shi-hua, \& Hu-qu, 2004; Yuan, 2017). The development and dissemination of hybrid rice varieties are important for bridging yield gaps and increasing rice yield potential in the tropics (Fischer, Byerlee, \& Edmeades, 2014). Hybrid rice is commercialized in China (Cao \& Zhan, 2014; Huang et al., 2017), the United States of America and other Asian countries like India, Vietnam, Philippines, Indonesia Bangladesh and Myanmar (International Rice Research Institute (IRRI), 1997; Virmani, 1994). Hybrid rice has so far not been exploited in Ghana. Ghana, like most sub Saharan African countries (El-namaky \& Demont, 2013) has just begun exploiting the potential of hybrid rice technology. Some introduced hybrid varieties have been found to out-yield the best available inbred variety by $15-20 \%$ (Abebrese et al., 2019).

Procedures for developing hybrid rice varieties are quite distinct from those employed in conventional inbred 
development (IRRI, 1997). Unlike conventional inbred rice development which accumulates productive genes that perform well under a homozygous condition year after year, hybrid breeding assembles and exploits productive genes in a heterozygous condition which increase the yield above the productive genes in the homozygous varieties (IRRI, 1997). Since the expression of heterosis is confined to the first generation only, farmers have to buy fresh seeds every season to raise a commercial crop. Since the hybrid varieties yield 15 to $20 \%$ more than the pure line varieties, farmers prefer hybrid seeds if the price is economically beneficial and seeds are reliably available (Virmani, 1994). Given that the cost of hybrid rice seed is normally high and requires a major investment, farmers are required to adopt seed saving and productive agronomic practices to enable them realize the expected yield benefits of hybrids (Spielman, Kolady, \& Ward, 2013). The hybrid system serves as a motivation and opportunity for private seed companies to recoup their investment (Breseghello \& Coelho, 2013; Spielman et al., 2013) and, as a result, encourages private-sector involvement in seed production research and development (El-namaky \& Demont, 2013; Spielman et al., 2013). Commercialization of hybrid varieties therefore requires a strong formal seed distribution channel which is well patronized by farmers.

In addition to the high yield potential, hybrids varieties are expected to possess other farmer trait preferences in relation to grain quality attributes and tolerance to local biotic and abiotic stresses (IRRI, 1997). Varieties of crops released in developing countries are often poorly adopted due to their failure to meet farmer and consumer trait preferences (Witcombe, Joshi, Joshi, \& Sthapit, 1996). Poor grain quality and susceptibility to diseases and pests are among the drawbacks of hybrid rice adoption in Asia (Virmani, Siddiq, \& Muralidharan, 1996). Farmer trait preferences vary from region to region and are, to some extent, linked to the major production constraints. Due to the heterozygous nature of hybrids, advanced knowledge on farmer trait preferences and their mode of inheritance will help breeders to develop strategies to enable the expression of desired traits in the resulting hybrid.

Participatory breeding approaches have been proposed as a way to increase farmer adoption of new varieties (Ceccarelli \& Grando, 2009; Witcombe et al., 1996) The participatory breeding approach has proved very successful and has become a model breeding approach in the West Africa sub-region (Somado, Guei, \& Keya, 2008). A means of identifying farmers' needs in a variety is a key component in farmer participatory approaches. One major participatory approach for identifying farmers' preferences in a variety is the participatory rural appraisal (PRA). PRA emphasizes local knowledge and assists local people in a community to make their own appraisal, analysis and plans (Asante et al., 2013; Danial et al., 2007).

To elicit information to assist local hybrid rice development, this study was carried out to identify key farmer preferred traits, assess farmers' general agronomic practices and the potential for adoption of hybrids.

\section{Methodology}

\subsection{Study Areas and Sampling Technique}

The core data for the study was obtained from a cross section of rice producers in the three established rice sector development hubs in Ghana, namely the Navrongo, Savelugu and Kumasi hubs (Note 1). The Novrongo hub is within the Kasena-Nankan district in the Upper East region of Ghana. This is within the Guinea savanna agro-ecological zone. The major rice production ecology is irrigated lowland. The Savelugu hub is within the Savelugu municipality of the Northern region of Ghana. The area lies in the Guinea savanna zone with rain-fed lowland as the major production ecology. Nobewam and Atia in the Ejisu-Juabeng district of Ashanti region were chosen to represent the Kumasi hub. The area is located in the semi-deciduous rainforest and the major production ecology is irrigated lowland.

The basic sample frame for the survey was rice sector development hubs in Ghana. The sampling process combined purposive and random procedures in the selection of the rice producers. The 3 rice development hubs were purposively selected whilst the selection of the rice farmers followed a simple random sampling technique using the farmers' group list. Overall the study involved 151 rice farmers.

\subsection{Data Collection and Analysis}

Data collection consisted of formal interviews with randomly selected rice farmers using a semi-structured questionnaire in the months of June to December, 2014. Information describing socio-economic characteristics, farm level characteristics, agronomic practices, farmers' preferred traits and willingness to cultivate hybrid rice were captured. Focus group discussions comprising 10 men and 5 women were also conducted in the three rice development hubs to augment the individual interviews. Farmers in each of these three rice development hubs were exposed to hybrid rice through on-farm hybrid rice demonstration plots.

The study combined both qualitative and quantitative analytical tools. Analysis of the data involved the use of 
descriptive statistics to describe the socio-economic characteristics of the farmers' household and farm characteristics.

\subsubsection{Kendall's Coefficient of Concordance}

Following from the listing and rankings of the preferences and constraints regarding the hybrid rice cultivation, the Kendall's Coefficient of Concordance (KCC) was used to test the level of agreement among the ranked constraints and preferences. The $\mathrm{KCC}$ is used to measure the extent of agreement or disagreement among rankings. The value of KCC is positive and ranges from a value of zero (which means there is maximum disagreement) to one (which means there is a perfect agreement). Following from Gearhart, Booth, Sedivec, \& Schauer (2013), the KCC is specified as follows:

$$
\begin{aligned}
& W=\frac{12 S}{P^{2}\left(n^{3}-n\right) p T} \\
& S^{\prime}=\sum_{i=1}^{n} R_{i}^{2}=S S R \\
& T=\sum_{k=1}^{m}\left(t_{k}^{3}-t_{k}\right)
\end{aligned}
$$

where $W$ is the KCC, $S$ is the sum-of-squares from row sums of ranks $R_{i}$ (as in Equation (2)), $n$ is the number of objects, $p$ is the number of judges and $T$ is a correction factor for tied ranks as specified in equation (3), $m$ is the number of groups and $t_{k}$ is the number of tied ranks in each ( $k$ ) of $\mathrm{m}$ groups (Siegel, 1956).

\section{Results}

\subsection{Socio-demographic Characteristics of Respondent Farmers}

The average age of a rice farmer in the study was 42 years. This was relatively higher than the average age in the Savelugu hub (Table 1). Male farmers constituted $76 \%$ of the sampled population. Eighty-Seven per cent (87\%) of the farmers were married whilst $11 \%$ were single. Sixty-two per cent $(62 \%)$ and $30 \%$ of the farmers in Savelugu and Navrongo hubs respectively, had no formal education. The situation was quite different from the Kumasi hub where $61 \%$ of the farmers had basic education. Quite a number $(5 \%)$ of the farmers had attained tertiary education. Agriculture is the primary occupation among the sampled rice producers (Table 1). Sixty-four percent $(64 \%)$ of the respondents also belonged to a farmer-based organization (FBO). The average farming experience of the farmers across hub was 17 years with average of 16 years for rice farming. 
Table 1. Demographic and socioeconomic characteristics of respondent farmers

\begin{tabular}{lllll}
\hline Variables & \multicolumn{3}{l}{ Rice Sector Development Hubs } \\
\cline { 2 - 5 } & $\begin{array}{l}\text { Kumasi } \\
(\mathrm{N}=53)\end{array}$ & $\begin{array}{l}\text { Navrongo } \\
(\mathrm{N}=48)\end{array}$ & $\begin{array}{l}\text { Savelugu } \\
(\mathrm{N}=50)\end{array}$ & $\begin{array}{l}\text { Overall } \\
(\mathrm{N}=151)\end{array}$ \\
\hline Age (years) & 46 & 43 & 36 & 42 \\
Sex of respondent (\%) & & & & \\
- Male & 70 & 69 & 90 & 76 \\
- Female & 30 & 31 & 10 & 24 \\
Marital Status (\%) & & & & \\
- Married & 81 & 94 & 86 & 86 \\
- Single & 17 & 4 & 12 & 11 \\
- Divorced & 0 & 2 & 0 & 1 \\
- Widowed & 2 & 0 & 2 & 2 \\
Level of Education (\%) & & & & \\
- Tertiary & 4 & 6 & 4 & 5 \\
- Secondary & 11 & 19 & 10 & 13 \\
- Basic & 61 & 28 & 20 & 37 \\
- Primary & 15 & 17 & 4 & 12 \\
- No Formal Education & 9 & 30 & 62 & 33 \\
Primary Occupation (\%) & & & & \\
- Agriculture & 98 & 94 & 92 & 95 \\
- Petty Trading & 0 & 2 & 0 & 1 \\
- Craftsmanship & 0 & 4 & 2 & 2 \\
- Teaching & 2 & 0 & 6 & 3 \\
Association of FBO (\%) & 65 & 92 & 36 & 64 \\
Household Size & 6 & 8 & 16 & 10 \\
Economically Active & 3 & 3 & 5 & 4 \\
Educated Household Members & 4 & 4 & 7 & 5 \\
Household Decision Maker (\%) & & & & \\
- Family head & 92 & 62 & 80 & 79 \\
- Spouse & 4 & 4 & 6 & 5 \\
- Children & 0 & 4 & 14 & 6 \\
- Head and Spouse & 4 & 23 & 0 & 9 \\
- Spouse and Children & 0 & 7 & 0 & 2 \\
Nativity (\%) & 85 & 100 & 100 & 95 \\
Farming Experience (years) & 20 & 17 & 22 & 17 \\
Rice Farming Experience (years) & 15 & 16 & 18 & 16 \\
\hline
\end{tabular}

Note. $\mathrm{FBO}=$ Farmer based organization

\subsection{General Farming Practices}

About 77 and $91 \%$ of the farmers in Kumasi and Navrongo hubs, respectively (irrigated ecology), cultivate rice twice in a year whereas $98 \%$ of the farmers in Savelugu (rainfed ecology) cultivate rice once in a year. Farmers in both Kumasi and Navrongo undertake transplanting but not in lines whilst farmers in the Savelugu mostly broadcast. Over $80 \%$ of the respondent rice farmers also cultivate maize. With the exception of land preparation, most of the farm operations are manual (Table 2). 
Table 2. General rice farming practices

\begin{tabular}{|c|c|c|c|c|}
\hline \multirow{2}{*}{ Variables } & \multicolumn{4}{|c|}{ Rice Sector Development Hubs } \\
\hline & $\begin{array}{l}\text { Kumasi } \\
(\mathrm{N}=53)\end{array}$ & $\begin{array}{l}\text { Navrongo } \\
(\mathrm{N}=48)\end{array}$ & $\begin{array}{l}\text { Savelugu } \\
(\mathrm{N}=50)\end{array}$ & $\begin{array}{l}\text { Overall } \\
(\mathrm{N}=151)\end{array}$ \\
\hline \multicolumn{5}{|l|}{ Ecology $(\%)$} \\
\hline - Rain fed Upland & 0 & 4 & 4 & 3 \\
\hline - Rain fed Lowland & 35 & 30 & 96 & 54 \\
\hline - Irrigated Lowland & 65 & 66 & 0 & 44 \\
\hline \multicolumn{5}{|l|}{ Rice cultivation in a year $(\%)$} \\
\hline - Once & 21 & 9 & 98 & 43 \\
\hline - Twice & 77 & 91 & 2 & 56 \\
\hline - Three times & 2 & 0 & 0 & 1 \\
\hline \multicolumn{5}{|l|}{ Method of planting (\%) } \\
\hline - Transplanting in lines & 24 & 11 & 0 & 12 \\
\hline - Transplanting (Not in lines) & 61 & 81 & 2 & 48 \\
\hline - Dibbling in lines & 4 & 9 & 24 & 12 \\
\hline - Dibbling (Not in lines) & 9 & 0 & 2 & 4 \\
\hline - Broadcasting & 2 & 0 & 72 & 25 \\
\hline \multicolumn{5}{|l|}{ Cultivation of other crops (\%) } \\
\hline - Yes & 92 & 100 & 98 & 97 \\
\hline - No & 8 & 0 & 2 & 3 \\
\hline \multicolumn{5}{|l|}{ Other crops cultivated (\%) } \\
\hline - Maize & 72 & 94 & 98 & 88 \\
\hline - Vegetables & 4 & 2 & 2 & 3 \\
\hline - other crops & 23 & 4 & 0 & 9 \\
\hline \multicolumn{5}{|l|}{ Type of labor $(\%)$} \\
\hline - Family & 75 & 63 & 78 & 72 \\
\hline - Hired & 20 & 31 & 10 & 21 \\
\hline • Communal & 5 & 6 & 12 & 7 \\
\hline \multicolumn{5}{|c|}{ Use of motor-powered equipment (\%) } \\
\hline - Yes & 64 & 96 & 98 & 85 \\
\hline • No & 36 & 4 & 2 & 15 \\
\hline \multicolumn{5}{|l|}{ Type of machine used (\%) } \\
\hline - Plough & 36 & 21 & 68 & 41 \\
\hline - Power tiller & 64 & 75 & 12 & 50 \\
\hline - Combine harvester & 0 & 0 & 20 & 9 \\
\hline \multicolumn{5}{|l|}{ Method of Land acquisition (\%) } \\
\hline - Rent & 86 & 28 & 0 & 39 \\
\hline - Own & 8 & 32 & 30 & 23 \\
\hline - Inherited & 0 & 21 & 52 & 24 \\
\hline - Sharecropping & 0 & 2 & 2 & 1 \\
\hline - Family land & 6 & 17 & 16 & 13 \\
\hline
\end{tabular}

\subsection{Farmer Preferred Traits and Why They Are Cultivating Their Current Varieties}

High yield, early maturity and grain quality (available market, good taste, aroma and long grains) were the three main reasons most of the farmers consider in selecting a variety (Table 3). However, the reasons differ slightly across the rice sector development hubs. Farmers in Kumasi hub chose a particular variety based on its high yield, good taste, available market, early maturity and good aroma. For the northern hubs (Savelugu and Navrongo), some variation was seen. Whereas farmers in the Navrongo hub favor high yield, available market, early maturity, good taste and easy harvesting, their counterparts in the Savelugu hub consider high yield, early maturity, weed tolerance, drought tolerance, and available market in selecting their variety (Table 3). 
Table 3. Farmer preferred traits and reasons they are cultivating their current varieties

\begin{tabular}{lllll}
\hline \multirow{2}{*}{ Trait/variables } & \multicolumn{4}{c}{ Rice Development Hubs } \\
\cline { 2 - 5 } & Kumasi (N=53) & Navrongo (N=48) & Savelugu (N=50) & Overall (N=151) \\
\hline High Yielding & 27.7 & 34.5 & 36.6 & 32.6 \\
Early Maturity & 12.3 & 19 & 14.6 & 15.0 \\
Available market* & 13.5 & 6.9 & 21.2 & 14.2 \\
Good taste & 19.4 & 0.9 & 12.4 & 11.8 \\
Good Aroma & 9 & 1.7 & 6.6 & 6.1 \\
Drought tolerance & 5.8 & 12.5 & 0 & 5.9 \\
Weed tolerance & 1.3 & 15.5 & 0 & 4.9 \\
Long grains & 6.5 & 3.4 & 0.7 & 3.7 \\
Easy to thresh & 0 & 0 & 6.9 & 2.2 \\
Seeds can be recycled & 3.9 & 0 & 0 & 1.5 \\
Disease resistance & 0 & 4.3 & 0.7 & 1.5 \\
Good germination & 0.6 & 0.9 & 0.7 & 0.7 \\
\hline
\end{tabular}

Note. *demand by the market due to superior grain quality

\subsection{Farmer Varietal Preferences and Patronage of the Formal Seed Sector}

Fifty-two per cent (52\%) of the farmers grow Jasmine 85, 8\% grow AgraRice and 1\% growing Nabogu. The remaining $39 \%$ grow other varieties which are all inbreds. Twenty-two per cent $(22 \%)$ of the farmers in the Kumasi hub however cultivate AgraRice. Most farmers in Savelugu hub were found to cultivate other varieties which are not officially released. Fifty per cent (50\%) of the farmers continue to use self-saved seeds. The habit of using self-saved seeds was more pronounced in the Savelugu hub followed by the Kumasi hub. Nevertheless, $81 \%$ of the farmers in Navrongo hub purchase seeds. With respect to those who buy seeds, the ministry of food and agriculture (MoFA) was the main source $(55 \%)$ followed by the open market (26\%). Research and private seed companies contributed $2 \%$ and $1 \%$ respectively to the seed market. Fifteen percent (15\%) of the farmers also patronize the informal seed system (Table 4).

Table 4. Farmers' varietal preferences and patronage of the formal seed system

\begin{tabular}{|c|c|c|c|c|}
\hline \multirow[b]{2}{*}{ Variables } & \multicolumn{4}{|c|}{ Rice Sector Development Hubs } \\
\hline & $\begin{array}{l}\text { Kumasi } \\
(\mathrm{N}=53)\end{array}$ & $\begin{array}{c}\text { Navrongo } \\
(\mathrm{N}=48)\end{array}$ & $\begin{array}{l}\text { Savelugu } \\
(\mathrm{N}=50)\end{array}$ & $\begin{array}{l}\text { Overall } \\
(\mathrm{N}=151\end{array}$ \\
\hline \multicolumn{5}{|l|}{ Source of seeds $(\%)$} \\
\hline - Self-saved seed & 43 & 19 & 84 & 50 \\
\hline - Buy & 49 & 81 & 16 & 47 \\
\hline - Family and friends & 8 & 0 & 0 & 3 \\
\hline \multicolumn{5}{|c|}{ Source of seed purchase $(\%)$} \\
\hline - MoFA & 66 & 65 & 24 & 55 \\
\hline - SARI & 0 & 6 & 0 & 2 \\
\hline - Seed company & 4 & 0 & 0 & 2 \\
\hline - Open market & 28 & 2 & 66 & 26 \\
\hline - Others & 2 & 27 & 10 & 15 \\
\hline \multicolumn{5}{|l|}{ Varieties (\%) } \\
\hline - Jasmine 85 & 66 & 75 & 16 & 52 \\
\hline - Nabogu & 0 & 0 & 2 & 1 \\
\hline - AgraRice & 23 & 2 & 2 & 8 \\
\hline - Others & 11 & 23 & 80 & 39 \\
\hline \multicolumn{5}{|c|}{ Perception of rice yields over the years (\%) } \\
\hline - Increasing & 72 & 65 & 18 & 52 \\
\hline - Decreasing & 26 & 31 & 80 & 45 \\
\hline - The same & 2 & 4 & 2 & 3 \\
\hline \multicolumn{5}{|c|}{ Preference for higher yielding variety (\%) } \\
\hline - Yes & 100 & 100 & 100 & 100 \\
\hline
\end{tabular}

Note. SARI=Savanna Agricultural Research Institute, MoFA= Ministry of Food and Agriculture 


\subsection{Farmers' Knowledge and Willingness to Cultivate Hybrid Rice}

The majority (80\%) of farmers did not have previous knowledge of hybrid rice (Table 5). The lack of knowledge of hybrid rice was more pronounced among farmers in the Navrongo hub followed by farmers in Savelugu and Kumasi hub. With reference to farmers' experience with hybrid maize and the on-farm hybrid demonstrations, majority $(73 \%)$ of the farmers in all the hubs were willing to cultivate hybrid rice. Fifty-one percent (51\%) of the farmers in the Savelugu hub were however unwilling to cultivate hybrid rice largely due to the fact that the seeds cannot be reused for subsequent planting season. Ninety-eight per cent (98\%) and $72 \%$ of the farmers in the Kumasi and Navrongo hubs, respectively, were willing to cultivate hybrids. In order to justify buying new seeds for planting every season, 59\% of the sampled farmers were expecting a minimum of 50\% yield advantage over their currently grown variety to guarantee adoption (Table 5).

Table 5. Knowledge and farmers' willingness to cultivate hybrid rice

\begin{tabular}{lllll}
\hline Which varieties do you cultivate & \multicolumn{4}{l}{ Rice Sector Development Hubs } \\
\cline { 2 - 5 } & $\begin{array}{c}\text { Kumasi } \\
(\mathrm{N}=53)\end{array}$ & $\begin{array}{c}\text { Navrongo } \\
(\mathrm{N}=48)\end{array}$ & $\begin{array}{l}\text { Savelugu } \\
(\mathrm{N}=50)\end{array}$ & $\begin{array}{l}\text { Overall } \\
(\mathrm{N}=151)\end{array}$ \\
\hline $\begin{array}{l}\text { *Knowledge of hybrid rice (\%) } \\
\text { - Yes }\end{array}$ & 35 & 8 & 16 & 20 \\
$\quad$ - No & 65 & 92 & 84 & 80 \\
Will you cultivate hybrid rice for subsequent season & & & & \\
- Yes & 98 & 72 & 48 & 73 \\
- No & 2 & 28 & 52 & 27 \\
Minimum expected yield advantage & & & & \\
- $10 \%$ & 0 & 13 & 0 & 4 \\
- $30 \%$ & 2 & 52 & 18 & 19 \\
- 50\% & 98 & 35 & 42 & 59 \\
- 51\% and above & 0 & 0 & 40 & 18 \\
\hline
\end{tabular}

Note. * Knowledge of hybrid rice include all sources of encounter (head of it, seen it somewhere, ever cultivated it, involved in a demonstration with it etc.

Farmers were generally not ready to pay above GHC $4(\$ 1)$ for a kilo of hybrid rice seeds. A test of significance in the means of the amount farmers were willing to pay for hybrid rice indicated a significant difference across the hubs at $5 \%$ (Table 6).

Table 6. One Way ANOVA test for prices farmers are willing to pay for hybrid rice

\begin{tabular}{lllll}
\hline Variables & $\begin{array}{l}\text { Kumasi } \\
(\mathrm{N}=53)\end{array}$ & $\begin{array}{l}\text { Navrongo } \\
(\mathrm{N}=48)\end{array}$ & $\begin{array}{l}\text { Savelugu } \\
(\mathrm{N}=50)\end{array}$ & $\begin{array}{l}\text { Overall } \\
(\mathrm{N}=151)\end{array}$ \\
\hline Price willing to pay for hybrid rice $(\mathrm{GH} \phi)$ & $\begin{array}{l}4.430 \\
2.111\end{array}$ & 3.119 & 3.274 \\
$\mathrm{~F}(2,140)$ & 3.600 & & & \\
Sig. & $0.030^{* *}$ & & & \\
\hline
\end{tabular}

Note. $* *$ Significant at $5 \%$ level, $\$ 1=\mathrm{GH} \phi 4$

\section{Discussion}

\subsection{Socio-demographic Characteristics of Respondent Farmers}

The average age of 42 years for a rice farmer in the study was relatively young compared to the average age of farmers in other important crop commodities such as cocoa with average farmer age of over 50 years (MoFA, 2010). Farmers in the Savelugu hub were relatively younger compared to the average in the study. It was encouraging to see most of the farmers belonging to the economically active age group. This implies reasonable sustainability for the rice sector if given the right investment. However, the fact that only $24 \%$ of the sampled farmers were female suggests that more effort is required in the area of gender mainstreaming in rice production. Though women are known be active players in the rice sector, their involvement is mostly in the processing aspect. More women could be encouraged to also grow the crop if the difficulty with regard to land acquisition is addressed. The available farmlands often turn to be in the hands of men (Ragasa \& Chapoto, 2017; Ragasa, Dankyi, Acheampong, Wiredu, \& Chapoto, 2013). Marriage is a highly cherished institution among many Africans for which Ghana is no exception. In a typical farm household, spouses and children complement each 
other with respect to work both in and outside the farm. This may explain why over $87 \%$ of the farmers were married and dependent on the family as the primary source of labor. Education plays a major role in the adoption of agricultural technologies. It empowers individual to make informed decisions. The education level of the farmers was very low; for instance, over $62 \%$ and $30 \%$ of the farmers had no formal education in Savelugu and Navrongo hubs respectively. Only 5\% of the farmers had attained tertiary education. Typical of subsistence agriculture, the majority of the farmer cultivate other crops; mostly maize (MoFA, 2010) and do other jobs for a buffer. The revelation that $64 \%$ of the respondents belong to an association was very encouraging. Membership in farmer based organizations enables the farmers to jointly work together to achieve a common goal. It also facilitates credit acquisition and other forms of support to the farmers. Almost all the farmers were natives. Nativity ensures access to social resources such as land and other resources for production and also carries certain privileges. With an average of 16 years' experience in rice farming, the farmers could be considered to be experienced enough to assess different rice production technologies.

\subsection{General Farming Practices}

Majority of the farmers still employing old inefficient practices such as broadcasting and transplanting haphazardly is an indication that adoption level of improved agronomic practices is still low. A seeding rate of 50 $\mathrm{kg} / \mathrm{ha}$ is recommended for the lowland rainfed by dibbling (Ragasa et al., 2013). This rate could be reduced to as low as $20 \mathrm{~kg} / \mathrm{ha}$ when single seedling are transplanted in lines in the irrigated ecology. High cost of hybrid rice seeds will require that farmers move from the current extensive way of cultivating rice to a more intensive system to derive the expected benefit. Since the cost of hybrid rice seeds alone is a major investment, farmers will have to desist from broadcasting in order to minimize the amount of seeds required. It came out in a discussion that, most farmers have refused to transplant in lines even after the extensive training they have received through the participatory learning and action research (PLAR) and the system of rice intensification (SRI) projects (Dzomeku, Sowley, \& Yussif, 2016). Although farmers have always complained that transplanting in rows is labor intensive and time consuming, the end benefits in terms of increased yield, seed saving and ease of carrying out farm operations such as weeding have clearly been demonstrated (Ragasa et al., 2013).

As specified by Ragasa et al. (2013), besides land preparation, almost all farm operations were manual. Mechanization of major farm operations such as planting, weeding and harvesting need urgent attention to enable farmers minimize labor costs and increase their farm holdings. Due to the availability of irrigation facilities, farmers at Nobewam and Navrongo were able to cultivate rice twice a year while their counterparts at Savelugu do only once. Rice is produced in Ghana under three ecologies; rainfed lowland (76\%), irrigated lowland (16\%) and rainfed uplands (8\%) with corresponding average yields of $2.4 \mathrm{t} / \mathrm{ha}, 4.5 \mathrm{t} / \mathrm{ha}$ and $1.0 \mathrm{t} / \mathrm{ha}$, respectively (Ragasa \& Chapoto, 2017). Considering the characteristic low yield and erratic rainfall pattern of the rainfed lowland ecology, which is generally regarded as offering the best opportunity for increasing rice production in Ghana (Japan International Copreration Agency (JICA), 2008), it will be very prudent to expand the area under irrigation and make the irrigated ecology the focus for hybrid rice technology dissemination. Although expansion will require huge capital investment and expertise in irrigation management, it will eventually pay off with increased yields and frequency of cultivation.

\subsection{Farmer Trait and Varietal Preferences and Patronage of the Formal Seed Sector}

High yield, early maturity, and superior grain quality were farmers' top three traits. Grain quality was expressed by farmers in varying ways such as good taste, presence of aroma, long grains and availability of market. Due to the influx of imported premium Jasmine and Basmati styled rice from Thailand and the US in the Ghanaian market (Asante et al., 2013; Ragasa et al., 2013), locally developed varieties should have their grain quality attributes match the imported brands to be marketed successfully. As reported by Anang, Adjetey, \& Abiriwe, (2011) and Asante et al., 2013), the Ghanaian market has high preference for intermediate amylose and long slender aromatic rice grains, with these characters accounting for over $40 \%$ increase in price quotations. Aroma for instance is becoming a must have trait in a new variety especially for the urban people who are used to eating imported rice (Ragasa \& Chapoto, 2017). Early maturity was perhaps farmers' second most important trait because it is mostly used as an escape mechanism for drought especially in the rainfed ecology. Farmers probably ranked diseases less important than other traits because their currently grown varieties were bred for resistance to known local diseases and do not normally encounter serious disease problems except cases of resistance breakdown. Aside yield, development of local rice hybrids should therefore be mindful of the grain quality and maturity period of the final products. The superior grain quality of Jasmine 85 positioned it as the highest grown variety. This was in line with earlier reports by Asante et al., (2013) and Ragasa et al., (2013). AgraRice was however found to be increasingly becoming popular at Nobewam and Novrongo and could replace Jasmine 85 in these hubs due to its high yield and the resistance breakdown of Jasmine 85 to rice blast 


\section{(Pyricularia oryzae).}

As indicated by Ragasa et al. (2013), most farmers (in our case 50\%) continue to use self-saved seeds. Farmers gave mistrust and unavailability of seeds when needed as the main reasons for their low patronage and reliance of the formal seed system. Farmers recounted instances where their own saved seeds performed better than purchased certified seeds. This calls for tightening the regulation process of the formal seed system. Farmers also gave instances where they had to travel long distances to district and regional capitals to access certified seeds. This situation is expected to minimize as a result of AGRA's (Alliance for a green revolution in Africa) special initiative to empower private seed companies to deliver quality seeds at proximity to farmers. The revelation that $81 \%$ of the rice farmers in the Navrongo hub purchase seeds suggest that farmers may buy seeds if there is a trusted reliable supplier. An established multi-stakeholder platform within the Navrongo hub with specially trained group to supply seed was their main source of certified seed. The ministry of food and agriculture (MoFA) was farmers' main source of purchased seeds with the private seed companies accounting for just a small portion of the seed market. The private seed companies will have to work hard to get visibility and a large portion of the seed market before hybrids could be introduced.

\subsection{Farmers' Knowledge and Willingness to Cultivate Hybrid rice}

Eighty per cent $(80 \%)$ of the respondent farmers who were also identified as maize producers had no knowledge on hybrids. The common example of the use of hybrid varieties in Ghanaian agriculture is in maize (MoFA, 2010). Good quality maize hybrids have been available in the last few years after changes in the Ghanaian seed laws (MoFA, 2010). Ghanaian rice farmers are used to replanting self-saved seeds. Some farmers involved in the hybrid evaluation demonstrations had already picked panicles and replanted on portions of their fields the following season. Extension education on the need not to replant hybrid seeds will be needed.

One problem associated with the adoption of hybrid varieties is the high cost of seeds. Farmers generally didn't like the idea that hybrid rice seeds are not to be replanted. Majority of the farmers as a result were expecting a minimum of 50\% yield advantage over their currently grown variety to guarantee adoption of hybrid varieties. This expected yield advantage is quite huge since a yield advantage of $15-20 \%$ is currently possible (Abebrese et al., 2019; El-namaky \& Demont, 2013; IRRI, 1997). Thus, the realizable yield advantage of hybrids will be a major determinant for adoption. Initial cost study indicated that farmers were not ready to pay above GHC $4(\$ 1)$ for a kilo of hybrid rice seed (Table 6). Farmers were willing to pay just a little above the released prices of GHC 2 and GHC 2.30 for certified seeds of inbreds in 2013 and 2014 respectively (MoFA, 2014, 2015). Compared to the anticipated price of GHC 20 (\$5) per kilo from interested private seed companies (Roland Quaye, WIENCO-Ghana, personal communication) which have already begun testing hybrid varieties from Asia, there will be a need for reasonable pricing such that the return from growing hybrid seed is high enough for farmers to see the value of growing hybrids. Thus, farmers want increased profits so the yield of pure line varieties and profits based on income they produce must be compared to yield of hybrids and the net profits from them.

\section{Conclusion}

Farmers will prefer high yielding early maturing rice varieties with superior grain quality. Farmers' knowledge on hybrid varieties is very low. There would be the need to educate farmers especially on the need not to re-plant hybrid rice seeds. Farmers would have to adopt productive agronomic practices that enable seed saving. The private sector led seed system to support hybrid rice commercialization is currently weak. The cost of hybrid rice seed will be a problem. There will be the need for reasonable pricing such that the return from growing hybrid seed is high enough for farmers to see the value of growing it. Considering the expected yield advantage and the price farmers will like to pay, the prospects of hybrid rice adoption in Ghana could said to be very low.

\section{Acknowledgement}

Many thanks to the Alliance for a Green Revolution in Africa (AGRA) for funding this research through the West Africa Centre for Crop Improvement (WACCI), University of Ghana.

\section{References}

Abebrese, S. O., Yeboah, A., Dogbe, W., Kofi, P., Dartey, A., Akromah, R., ... Danquah, E. Y. (2019). Evaluation of Yield, Reaction to Diseases, and Grain Physical Attributes of Some Introduced Rice Hybrids in Ghana. International Journal of Agronomy, 2019. https://doi.org/10.1155/2019/3926765

Anang, B. T., Adjetey, S. N. A., \& Abiriwe, S. A. (2011). The consumer preferences for rice quality characteristics and the effect on price in the Tamale Metropolis, Northern Region, Ghana. International Journal for Agricultural Science, 1(2), 67-74. 
Asante, M. D., Asante, B. O., Acheampong, G. K., Offei, K., Gracen, V., Adu-dapaah, H., \& Danquah, E. Y. (2013). Farmer and consumer preferences for rice in the Ashanti region of Ghana: Implications for rice breeding in West Africa. Journal of Plant Breeding and Crop Science, 5(12), 229-238. http://doi.org/10.5897/JPBCS13.0409

Breseghello, F., \& Coelho, A. S. G. (2013). Traditional and modern plant breeding methods with examples in rice (Oryza sativa L.). Journal of Agricultural and Food Chemistry, 61(35), 8277-8286. http://doi.org/10.1021/jf305531j

Cao, L., \& Zhan, X. (2014). Chinese Experiences in Breeding Three-Line, Two-Line and Super Hybrid Rice. Rice - Germplasm, Genetics and Improvement, 279-308. http://doi.org/10.5772/56821

Ceccarelli, S., \& Grando, S. (2009). "Participatory plant breeding.” Cereals. New York, NY: Springer. http://doi.org/10.1007/978-0-387-72297-9

Cheng, S. H., Cao, L. Y., Zhuang, J. Y., Chen, S. G., Zhan, X. D., Fan, Y. Y., ... Min, S. K. (2007). Super hybrid rice breeding in China: Achievements and prospects. Journal of Integrative Plant Biology. http://doi.org/10.1111/j.1744-7909.2007.00514.x

Danial, D., Parlevliet, J., Almekinders, C., \& Thiele, G. (2007). Farmers ' participation and breeding for durable disease resistance in the Andean region. Euphytica, 153(3), 385-396. http://doi.org/10.1007/s10681-006-9165-9

Dzomeku, I. K., Sowley, E. N. K., \& Yussif, I. S. (2016). Evaluation of System of Rice Intensification ( SRI ) for Enhanced Rice ( Oryza sativa L . ) Production in the Guinea Savannah Zone of Ghana, Current Agricultural Research Journal 4(1), 84-93. https://doi.org/10.12944/CARJ.4.1.09

El-namaky, R. A., \& Demont, M. (2013). Hybrid Rice in Africa : Challenges and Prospects. In M. C. S. Wopereis, D. E. Johnson, N. Ahmadi, E. Tollens, \& A. Jalloh (Eds.), Realizing Africa's Rice promise (pp. 173-178). UK: CAB international. https://doi.org/10.1079/9781845938123.0173

Fischer, T., Byerlee, D., \& Edmeades, G. (2014). Crop yields and global food security; will yield increase continue to feed the world? Australian Centre for International Agricultural Research. Canberra: Australian Centre for International Agricultural Research. http://doi.org/ISBN 9781925133066 (PDF)

Gearhart, A., Booth, D. T., Sedivec, K., \& Schauer, C. (2013). Use of Kendall's coefficient of concordance to assess agreement among observers of very high resolution imagery. Geocarto International, 28(6), 517-526. Retrieved from doi: 10.1080/10106049.2012.725775

Huang, M., Jiang, P., Shan, S., Gao, W., Ma, G., Zou, Y., ... Yuan, L. (2017). Higher yields of hybrid rice do not depend on nitrogen fertilization under moderate to high soil fertility conditions. Rice, 10(1), 1-5. http://doi.org/10.1186/s12284-017-0182-1

IRRI. (1997). Hybrid Rice Breeding Manual. Los Banos, Laguna, Philippines: International Rice Research Institute.

Japan Internation Cooperation Agency. (2008). The study on the promotion of domestic rice in the Republic of Ghana (Final Report). Accra, Ghana.

MoFA. (2010). Agriculture in Ghana, Facts and Figures. Accra, Ghana: MoFA.

MoFA. (2014). Agreed prices of seeds for 2014 cropping season. Accra, Ghana: Ministry of Food and Agriculture (MoFA).

MoFA. (2015). Agreed prices of seeds for 2015 cropping season. Accra, Ghana: Ministry of Food and Agriculture (MoFA).

Ragasa, C., \& Chapoto, A. (2017). Land Use Policy Limits to Green Revolution in rice in Africa: The case of Ghana. Land Use Policy, 66(March), 304-321. http://doi.org/10.1016/j.landusepol.2017.04.052

Ragasa, C., Dankyi, A., Acheampong, P., Wiredu, A. N., \& Chapoto, A. (2013). Patterns of Adoption of Improved Rice Technologies in Ghana. International Food Polycy Research Instiitute, 35(July,2013), 1-36.

Shi-hua, C. H., Li-yong, C. A. O., Shi-hua, Y. A. N. G., \& Hu-qu, Z. H. A. I. (2004). Forty Years ' Development of Hybrid Rice: China's Experience Developmental History of Hybrid Rice Experience of Hybrid Rice Breeding. Rice Science, 11(5-6), 225-230.

Siegel, S. (1956). Nonparametric Statistics for the Behavioral Sciences. New York: McGraw- Hill.

Somado, E. A., Guei, R. G., \& Keya, S. (2008). NERICA: the New Rice for Africa - a Compendium. A 
Compendium, 210. http://doi.org/10.13140/RG.2.1.3633.4800

Spielman, D. J., Kolady, D. E., \& Ward, P. S. (2013). The prospects for hybrid rice in India. Food Security, (1), 651-665. http://doi.org/10.1007/s12571-013-0291-7

Tanko, M., \& Amikuzuno, J. (2015). Effects of Rice Importation on the Pricing of Domestic Rice in Northern Region of Ghana. ABC Resarch Alert, 3(2), 23-36.

Virmani, S. (1994). Heterosis and hybrid rice breeding (vol. 22). Berlin: Springer Science \& Business Media. https://doi.org/10.1007/978-3-642-85115-5

Virmani, S. S., Siddiq, E. A., \& Muralidharan, K. (Eds.). (1996). Advances in Hybrid Rice Technology. In Proceedings of the 3rd International Symposium on Hybrid Rice (p. 443 p). 14-16 November 1996, Hydrebad, India: International Rice Research Institute, Manila (Philippines).

http://doi.org/10.1017/S001447970031211X

Witcombe, J. R., Joshi, A., Joshi, K. D., \& Sthapit, B. R. (1996). Farmer Participatory Crop Improvement. I. Varietal Selection and Breeding Methods and Their Impact on Biodiversity. Experimental Agriculture, 32(04), 445. http://doi.org/10.1017/S0014479700001526

Yuan, L. (2017). Progress in super-hybrid rice breeding. Crop Journal, 5(2), 100-102. http://doi.org/10.1016/j.cj.2017.02.001

\section{Notes}

Note 1. Rice development hubs are zones where rice research products and technology are tested and all partners in the rice development value chain are located.

\section{Copyrights}

Copyright for this article is retained by the author(s), with first publication rights granted to the journal.

This is an open-access article distributed under the terms and conditions of the Creative Commons Attribution license (http://creativecommons.org/licenses/by/3.0/). 